\title{
Digitalis and atrial tachycardia with block
}

\author{
Ole Storstein and Knut Rasmussen \\ From the Medical Department B, University Hospital, Rikshospitalet, Oslo, Norway
}

Atrial tachycardia with block is usually considered to be caused by digitalis intoxication. We have reviewed 44 episodes in 31 patients seen during the past three years. None of the patients fulfilled Lown's criteria for considering digitalis to be the common aetiological factor in atrial tachycardia with block. In our patients the concentration of serum digitoxin was between I5 and $25 \mathrm{ng} / \mathrm{ml}$ in 18 patients; 7 patients had somewhat higher concentrations, while 5 had concentrations below $15 \mathrm{ng} / \mathrm{ml}$ (therapeutic range $15-25 \mathrm{ng} / \mathrm{ml}$ ). A prospective study of digitalis intoxication in our hospital has shown a lower incidence (about 5 per cent) of intoxication than previously reported. Our study suggests that atrial tachycardia with block is seldom caused by digitalis intoxication. In most of our cases atrial arrhythmia appeared in those with organic heart disease; and here the prognosis is better than had been previously thought. These findings, which are at variance with previous reports, may be related to the special type of patients treated, as most of our patients had valvular or congenital heart disease and were referred for cardiac surgery.

Paroxysmal atrial tachycardia with block was originally diagnosed by Lewis (1909) from polygraphic recording of jugular and radial pulses. Mackenzie (I9II) first suggested that this form of tachycardia was caused by digitalis. Since that time digitalis has been considered to be the dominant factor in producing atrial tachycardia with block (Lown, Wyatt, and Levine, 1960; Hejtmancik, Herrmann, and Wright, 1958; Oram, Resnekov, and Davies, 1960; Harris, Julian, and Oliver, 1960; Goldberg et al., 1960; Burton, 1962; Agarwal and Agrawal, 1972).

A less frequent occurrence of digitalis intoxication as the cause of paroxysmal atrial tachycardia with block has, however, been observed by Freiermuth and Jick (1958), Morgan and Breneman (1962), and Hillestad (1969).

$\mathrm{Up}$ to now the diagnosis of digitalis intoxication has been made on clinical and electrocardiographic grounds. The introduction into clinical medicine of methods to determine serum concentrations of digitalis glycosides should make it possible to verify or reject the diagnosis of digitalis toxicity. Apart from the study of Smith and Haber (1970) we are not aware of other reports on the determination of levels of digitalis in patients with paroxysmal atrial tachycardia with block. We are therefore reporting our experience of 44 episodes in 31 patients with this arryhthmia.

Received 28 August 1973.

\section{Subjects and methods}

This patient series was collected during the years 1969 to 1972 , and comprises 31 patients. All patients seen during this period with atrial tachycardia with block are included. In Io of the patients there were repeated episodes of paroxysmal atrial tachycardia with block. The diagnosis of atrial tachycardia with block was made according to the criteria put forward by Lown et al. (1960): 'An atrial rate between 150-250 per minute, an isoelectric baseline between the P-waves in all leads and the existence of atrio-ventricular block beyond simple prolongation of the PR interval'. In some of the patients the diagnosis was confirmed by oesophageal leads. In this series, like that of Hillestad, atrial tachycardia with block did not consistently appear in paroxysms. Consequently the prefix 'paroxysmal' has been omitted in the following.

Serum determination of digotoxin has been carried out by the ${ }^{86} \mathrm{Rb}$ method of Lowenstein and Corrill (1966) as modified by Gierdrum (1970). This method is based on the ability of digitalis glycosides to inhibit ion flux across red cell membranes. This method has proved to be accurate and reproducible (Rasmussen, Jervell, and Storstein, 1971).

\section{Results}

The ages of the patients and diagnoses are presented in Table I. There were 14 patients with valvular heart disease, 6 with congenital heart disease, and only I with ischaemic heart disease. The other patients had miscellaneous heart disorders. The age 
TABLE I Composition of series studied, including diagnoses and drug regimen

\begin{tabular}{|c|c|c|c|c|c|c|c|}
\hline Case No. & Sex & Age & Diagnosis & $\begin{array}{l}\text { Duration } \\
\text { arrhythmia }\end{array}$ & Dose of digitoxin & Diuretics & Other toxic manifestations \\
\hline $\mathbf{I}$ & $\mathbf{F}$ & 52 & $\begin{array}{l}\text { Atrial tachycardia } \\
\text { with block }\end{array}$ & $2 \mathrm{yr}$ & $0.1 \mathrm{mg} 5 \mathrm{dy} / \mathrm{wk}$ & o & 0 \\
\hline 2 & $\mathbf{M}$ & 45 & $\begin{array}{l}\text { Aortic valve } \\
\text { replacement, } \\
\text { mitral stenosis }\end{array}$ & I yr & $0.05 \mathrm{mg} 5 \mathrm{dy} / \mathrm{wk}$ & 0 & 0 \\
\hline 3 & $\mathbf{F}$ & 62 & $\begin{array}{l}\text { Mitral stenosis } \\
\text { and } \\
\text { insufficiency }\end{array}$ & $\begin{array}{r}\text { Several } \\
\text { years }\end{array}$ & $0.1 \mathrm{mg} 5 \mathrm{dy} / \mathrm{wk}$ & $\begin{array}{l}\text { Frusemide } \\
40 \mathrm{mg} \text { alt. dy }\end{array}$ & $\begin{array}{l}0 \\
0\end{array}$ \\
\hline 4 & $\mathbf{M}$ & 46 & ASD & $20 \mathrm{yr} ?$ & $0.1 \mathrm{mg} 5 \mathrm{dy} / \mathrm{wk}$ & $\circ$ & 0 \\
\hline 5 & $\mathbf{M}$ & 62 & $\begin{array}{l}\text { Mitral + aortic } \\
\text { valve disease }\end{array}$ & $4 \mathrm{yr}$ & 0 & $\begin{array}{l}\text { Frusemide } \\
80 \mathrm{mg}\end{array}$ & 0 \\
\hline 6 & $\mathbf{F}$ & 62 & $\begin{array}{l}\text { Mitral + aortic } \\
\text { valve disease }\end{array}$ & I mth ? & $0.1 \mathrm{mg}$ & $\begin{array}{l}\text { Frusemide } \\
40 \mathrm{mg} \text { alt. dy }\end{array}$ & 0 \\
\hline 7 & $\mathbf{F}$ & 69 & SA block & Several yr? & $0.1 \mathrm{mg} 3 \mathrm{dy}$ & $\begin{array}{l}\text { Trichlormethiazide } \\
4 \mathrm{mg} \text { alt. dy }\end{array}$ & o \\
\hline 8 & $\mathbf{M}$ & 69 & Cardiomyopathy & $2 \mathrm{yr}$ & $0.1 \mathrm{mg}$ & 0 & 0 \\
\hline 9 & $\mathbf{F}$ & 49 & $\begin{array}{l}\text { Mitral + aortic } \\
\text { valve disease }\end{array}$ & $2 \mathrm{mth}$ & $0.1 \mathrm{mg} 5 \mathrm{dy} / \mathrm{wk}$ & 0 & $\circ$ \\
\hline 10 & $\mathbf{F}$ & 54 & $\begin{array}{l}\text { Mitral } \\
\text { commissurotomy }\end{array}$ & 2 mth & $0.1 \mathrm{mg}$ & $\begin{array}{l}\text { Frusemide } \\
40 \mathrm{mg}\end{array}$ & 0 \\
\hline II & $\mathbf{F}$ & 30 & ASD opn & $4 \mathrm{yr} ?$ & $0.05 \mathrm{mg} 6 \mathrm{dy} / \mathrm{wk}$ & $\begin{array}{l}\text { Trichlormethiazide } \\
4 \mathrm{mg} 4 \mathrm{dy} / \mathrm{wk}\end{array}$ & 0 \\
\hline I2 & $\mathbf{M}$ & 50 & $\begin{array}{l}\text { Mitral } \\
\text { commissurotomy }\end{array}$ & I yr & $0.1 \mathrm{mg}$ & 0 & 0 \\
\hline 13 & $\mathbf{M}$ & 69 & $\begin{array}{l}\text { AV block } \\
\text { pacemaker }\end{array}$ & $2 \mathrm{yr}$ & $0.1 \mathrm{mg} 5 \mathrm{dy} / \mathrm{wk}$ & $\begin{array}{l}\text { Frusemide } \\
40 \mathrm{mg}\end{array}$ & 0 \\
\hline 14 & $\mathbf{M}$ & 63 & Cardiomyopathy & I mth & 0.05 & $\begin{array}{l}\text { Trichlormethiazide } \\
4 \mathrm{mg} 5 \mathrm{dy} / \mathrm{wk}\end{array}$ & 0 \\
\hline 15 & $\mathbf{F}$ & 56 & $\begin{array}{l}\text { Mitral } \\
\text { commissurotomy }\end{array}$ & I mth & $0.1 \mathrm{mg} 5 \mathrm{dy} / \mathrm{wk}$ & 0 & 0 \\
\hline 16 & $\mathbf{M}$ & 49 & $\begin{array}{l}\text { Mitral valve } \\
\text { replacement }\end{array}$ & $?$ & $0.075 \mathrm{mg}$ & $\circ$ & 0 \\
\hline 17 & $\mathbf{F}$ & 67 & Mitral & $2 \mathrm{yr}$ & $0.1 \mathrm{mg} 5 \mathrm{dy} / \mathrm{wk}$ & $\circ$ & 0 \\
\hline 18 & $\mathbf{M}$ & 73 & AV block & I yr & $0.1 \mathrm{mg} 6 \mathrm{dy} / \mathrm{wk}$ & Hud-oblomthionide & o \\
\hline 19 & $\mathbf{M}$ & 73 & SA block & I yr & $0.1 \mathrm{mg} 5 \mathrm{dy} / \mathrm{wk}$ & $\begin{array}{l}\text { Hydrochlorothiazide } \\
25 \mathrm{mg} \text { alt. dy }\end{array}$ & o \\
\hline 20 & $\mathbf{F}$ & 56 & $\begin{array}{l}\text { Mitral } \\
\text { commissurotomy }\end{array}$ & I yr & $0.1 \mathrm{mg} 5 \mathrm{dy} / \mathrm{wk}$ & 0 & 0 \\
\hline 21 & $\mathbf{F}$ & 50 & ASD & $14 \mathrm{dy}$ & $0.05 \mathrm{mg}$ & $\begin{array}{l}\text { Frusemide } \\
40 \mathrm{mg} \text { alt. dy }\end{array}$ & 0 \\
\hline 22 & $\mathbf{M}$ & 52 & $\begin{array}{l}\text { Cardiac } \\
\text { aneurysm; opn }\end{array}$ & $14 \mathrm{dy}$ & $0.1 \mathrm{mg}$ & $\begin{array}{l}\text { Frusemide } \\
40 \mathrm{mg}\end{array}$ & 0 \\
\hline 23 & $\mathbf{F}$ & 52 & $\begin{array}{l}\text { Atrial } \\
\text { tachycardia } \\
\text { with block }\end{array}$ & Parox. & $0.1 \mathrm{mg} 5 \mathrm{dy} / \mathrm{wk}$ & 0 & 0 \\
\hline 24 & $\mathbf{F}$ & 50 & $\begin{array}{l}\text { WPW, } \\
\text { thyrotoxicosis }\end{array}$ & " & $0.1 \mathrm{mg} 6 \mathrm{dy} / \mathrm{wk}$ & 0 & 0 \\
\hline 25 & $\mathbf{M}$ & 50 & $\begin{array}{l}\text { Mitral } \\
\text { commissurotomy }\end{array}$ & , & $0.1 \mathrm{mg} 5 \mathrm{dy} / \mathrm{wk}$ & 0 & o \\
\hline 26 & $\mathbf{F}$ & 20 & SA block & I $\frac{1}{2}$ yr & $0.1 \mathrm{mg} 5 \mathrm{dy} / \mathrm{wk}$ & 0 & 0 \\
\hline 27 & $\mathbf{M}$ & 52 & $\begin{array}{l}\text { Aortic valve } \\
\text { replacement, } \\
\text { mitral insuffic. }\end{array}$ & r yr & $0.05 \mathrm{mg}$ & Dil & T- \\
\hline 28 & $\mathbf{M}$ & 49 & $\begin{array}{l}\text { Eisenmenger } \\
\text { complex }\end{array}$ & I mth & $0.1 \mathrm{mg}$ & $\begin{array}{l}\text { Ethacrynic acid } \\
50 \mathrm{mg} \text { alt. dy }\end{array}$ & Junctional tachycardia \\
\hline $\begin{array}{l}29 \\
30\end{array}$ & $\begin{array}{l}\mathbf{F} \\
\mathbf{M}\end{array}$ & $\begin{array}{l}52 \\
12\end{array}$ & ASD & 2 yr & $0.1 \mathrm{mg}$ & 0 & 0 \\
\hline 31 & $\stackrel{M}{M}$ & $\begin{array}{l}42 \\
44\end{array}$ & $\begin{array}{l}\text { Mitral valve } \\
\text { replacement, } \\
\text { tricuspid } \\
\text { insuffic. }\end{array}$ & $\begin{array}{l}3 \mathrm{yr} \\
1 \mathrm{wk}\end{array}$ & $\begin{array}{l}0.1 \mathrm{mg} 6 \mathrm{dy} / \mathrm{wk} \\
0.1 \mathrm{mg} 5 \mathrm{dy} / \mathrm{wk}\end{array}$ & $\begin{array}{l}\text { Frusemide } \\
40 \mathrm{mg} \text { alt. dy; } \\
\text { triameterene/50 mg }\end{array}$ & Junctional tachycardia \\
\hline
\end{tabular}


TABLE 2 Results of investigations, treatment given, and its effect

\begin{tabular}{|c|c|c|c|c|c|c|c|}
\hline Case No. & $\begin{array}{l}\text { Atrial } \\
\text { rate }\end{array}$ & $\begin{array}{l}\text { Ventricular } \\
\text { rate }\end{array}$ & $\begin{array}{l}\text { Digitoxin concn. } \\
(n g / m l)\end{array}$ & $\begin{array}{l}K \text {-concn. } \\
(m E q / l .)\end{array}$ & Treatment & Result & Control \\
\hline $\mathbf{I}$ & 220 & I10 & $22 \cdot 0$ & 4.4 & Digitalis cont'd & Sinus $6 \mathrm{dy}$ & Recurrent \\
\hline 2 & 270 & 90 & $36 \cdot 0$ & $4 \cdot 3$ & $\begin{array}{l}\text { Digitalis reduced } \\
\beta \text {-blocker }\end{array}$ & Sinus & I yr \\
\hline 3 & 300 & 150 & 10.5 & $3 \cdot 7$ & Digitalis cont'd & No effect & Sick sinus \\
\hline 4 & 160 & 67 & $12 \cdot 0$ & $5 \cdot 0$ & Digitalis cont'd & No effect & No effect \\
\hline 5 & 220 & 55 & $15 \cdot 0$ & 4.4 & $\begin{array}{l}\text { Digitalis cont'd } \\
\text { conversion }\end{array}$ & Sinus & Recurrent $2 \mathrm{mth}$ \\
\hline 6 & 220 & 105 & $28 \cdot 5$ & $4 \cdot I$ & $\begin{array}{l}\text { Digitalis omitted, } \\
\text { potassium, } \\
\text { conversion }\end{array}$ & Sinus & $\begin{array}{l}\text { Atrial fibrillation, } \\
\text { died after } \\
\text { mitral valve } \\
\text { replacement }\end{array}$ \\
\hline $\begin{array}{l}7 \\
8\end{array}$ & $\begin{array}{l}250 \\
160\end{array}$ & $\begin{array}{r}125 \\
80\end{array}$ & $\begin{array}{l}25.0 \\
13.5\end{array}$ & $\begin{array}{l}3 \cdot 8 \\
4 \cdot 8\end{array}$ & $\begin{array}{l}\text { Reduced digitalis } \\
\text { Digitalis omitted, } \\
\text { quinidine, } \\
\text { conversion }\end{array}$ & $\begin{array}{l}\text { SA block } \\
\text { Sinus }\end{array}$ & $\begin{array}{l}\text { Atrial fibrillation } \\
-\end{array}$ \\
\hline 9 & 160 & 62 & $24 \cdot 0$ & $4 \cdot 3$ & $\begin{array}{l}\text { Digitalis omitted, } \\
\text { quinidine, } \\
\text { conversion }\end{array}$ & Sinus & I yr \\
\hline I0 & 140 & 90 & $4: 5$ & $3 \cdot 8$ & $\begin{array}{l}\text { Digitalis omitted, } \\
\text { potassium, } \\
\text { conversion }\end{array}$ & $\begin{array}{l}\text { Atrial } \\
\text { fibrillation }\end{array}$ & 一 \\
\hline II & 240 & 105 & $12 \cdot 0$ & $4 \cdot 3$ & $\begin{array}{l}\text { Digitalis omitted, } \\
\text { quinidine, } \\
\text { potassium, } \\
\text { conversion }\end{array}$ & Sinus & Recurrent 2 yr \\
\hline 12 & 160 & 80 & $14 \cdot 0$ & $4 \cdot 0$ & $\begin{array}{l}\text { Digitalis omitted, } \\
\text { conversion }\end{array}$ & Sinus & Recurrent I mth \\
\hline 13 & 205 & 75 & 20.5 & $4 \cdot 8$ & Pacemaker & No effect & $\bar{n}$. \\
\hline 14 & 280 & 120 & $16 \cdot 0$ & 4.5 & $\begin{array}{l}\text { Digitalis omitted, } \\
\text { quinidine, } \\
\text { conversion }\end{array}$ & Sinus & Died I mth \\
\hline 15 & 220 & IIO & $20 \cdot 0$ & $4 \cdot 2$ & $\begin{array}{l}\text { Digitalis omitted, } \\
\text { quinidine, } \\
\text { conversion }\end{array}$ & Sinus & Recurrent I mth \\
\hline 16 & 195 & 95 & $19 \cdot 0$ & $5 \cdot 1$ & $\begin{array}{l}\text { Digitalis cont'd } \\
\text { quinidine } \beta \text {-blocker, } \\
\text { conversion }\end{array}$ & Sinus & Recurrent \\
\hline 17 & 220 & IIO & $23 \cdot 5$ & $5 \cdot 3$ & $\begin{array}{l}\text { Digitalis omitted } \\
\text { potassium, } \\
\text { conversion }\end{array}$ & Sinus & Recurrent 3 wk \\
\hline 18 & 230 & $70(\mathrm{PM})$ & $17 \cdot 0$ & $4 \cdot 7$ & Conversion & Sinus & $2 \mathrm{yr}$ \\
\hline 19 & 200 & 100 & $16 \cdot 5$ & $4 \cdot 1$ & $\begin{array}{l}\text { Digitalis omitted, } \\
\text { quinidine, } \\
\text { conversion }\end{array}$ & Sinus & I yr \\
\hline 20 & 250 & 125 & $16 \cdot 5$ & $4 \cdot 2$ & $\begin{array}{l}\text { Digitalis omitted, } \\
\text { quinidine, } \\
\text { conversion }\end{array}$ & Sinus & I mth \\
\hline $2 \mathbf{I}$ & 320 & 160 & $18 \cdot 5$ & $4 \cdot 0$ & $\begin{array}{l}\text { Digitalis omitted, } \\
\text { conversion }\end{array}$ & Sinus & $6 \mathrm{mth}$ \\
\hline 22 & 200 & 100 & $33 \cdot 5$ & $4 \cdot 7$ & $\begin{array}{l}\text { Digitalis omitted, } \\
\text { potassium, } \\
\text { conversion }\end{array}$ & Sinus & $2 \mathrm{yr}$ \\
\hline 23 & 180 & 130 & $20 \cdot 0$ & $4 \cdot 0$ & $\begin{array}{l}\text { Digitalis omitted, } \\
\beta \text {-blocker }\end{array}$ & Sick sinus & Atrial fibrillation \\
\hline 24 & 320 & 160 & $16 \cdot 0$ & $4 \cdot I$ & $\begin{array}{l}\text { Digitalis omitted, } \\
\text { quinidine, } \\
\beta \text {-blocker, } \\
\text { conversion }\end{array}$ & Sinus & Recurrent \\
\hline 25 & 280 & 140 & $28 \cdot 0$ & $4 \cdot 3$ & $\begin{array}{l}\text { Digitalis cont'd } \\
\text { quinidine }\end{array}$ & Sinus & $5 \mathrm{yr}$ \\
\hline 26 & 136 & 66 & II 0 & $4 \cdot 5$ & $\begin{array}{l}\text { Digitalis cont'd } \\
\beta \text {-blocker }\end{array}$ & Sinus & $4 \mathrm{yr}$ \\
\hline 27 & 240 & 80 & $18 \cdot 0$ & $4 \cdot 0$ & $\begin{array}{l}\text { Digitalis omitted, } \\
\text { potassium, } \\
\text { conversion }\end{array}$ & Sinus & $2 \mathrm{mth}$ \\
\hline 28 & 210 & 105 & $27 \cdot 5$ & $4 \cdot 6$ & $\begin{array}{l}\text { Digitalis omitted, } \\
\text { verapamil }\end{array}$ & Sinus & I mth \\
\hline 29 & I70 & 85 & $27 \cdot 5$ & $4 \cdot 2$ & $\begin{array}{l}\text { Digitalis omitted, } \\
\text { conversion }\end{array}$ & Sinus & Recurrent I mth \\
\hline 30 & 210 & 105 & $19 \cdot 0$ & $5 \cdot 0$ & $\begin{array}{l}\text { Digitalis omitted, } \\
\text { conversion }\end{array}$ & Nodal rhythm & $2 \mathrm{mth}$ \\
\hline 31 & 180 & 105 & $40 \cdot 0$ & 5.9 & $\begin{array}{l}\text { Digitalis omitted, } \\
\text { verapamil }\end{array}$ & Sinus & I mth \\
\hline
\end{tabular}


of the patients varied from 20 to 73 years, mean 52 years. There were 15 women and 16 men. The duration of the arrhythmia varied greatly, from 14 days up to several years. Three patients had paroxysmal atrial tachycardia.

Special regard has been given to the medication in these patients, especially to the dose of digitalis and diuretics. As will be seen from Table I, only one of the patients was not on digitalis before the study. In the other patients the dose of digitoxin varied from 0.05 to $0.1 \mathrm{mg}$ a day. Twelve of the patients were on diuretics before the study. They usually used moderate doses on an intermittent schedule.

In 17 patients there was 2-I AV block. A number of the other patients had 3-I block, some 4-I, and the others a varying AV block. The atrial rate ranged between 136 and 320 a minute. In 25 patients the atrial rate was within 150 to 250 a minute. Apart from those with rapid atrial rates above 250 the other criteria for atrial tachycardia with block, as previously described, were fulfilled.

None of the patients had low serum potassium (Table 2). In all, the concentration was within normal limits, with the exception of one who was on triamterene, who had a serum potassium level of $5.9 \mathrm{mEq} / 1$. All patients had normal renal function. Two patients had junctional tachycardia. Otherwise none of the patients exhibited other signs of digitalis toxicity.

The serum concentration of digitoxin varied from 4.5 to $40 \mathrm{ng} / \mathrm{ml}$. A prospective study on digitalis intoxication presently under way in our department has shown the therapeutic range of digitoxin concentration to be between 15 and $25 \mathrm{ng} / \mathrm{ml}$. Seven patients had concentrations above this upper limit and 5 below the lower limit. The patients with increased digitoxin concentration did not respond in a different way from those with a normal or low digitoxin concentration. None of them reverted to sinus rhythm after withdrawal of digitalis and the administration of potassium supplements.

Two patients (Cases 28 and 3I), were severely ill during their bouts of atrial tachycardia with block. Both had advanced cardiac failure and did not tolerate the rapid ventricular rate of 105 . Various antiarrhythmic agents were tried in these patients. Both responded to verapamil in a dose of $80 \mathrm{mg}$ every third hour. One of them returned to sinus rhythm and one is still in nodal rhythm with a rate of 55 (Fig. I).

As will be seen from Table 2, the treatment varied greatly in this patient group. None of the patients returned to sinus rhythm after withdrawal of digitalis and potassium supplements. Electroconversion was the most effective treatment, restoring sinus rhythm in I9 of the patients. In 7 patients sinus rhythm was obtained by antiarrhythmics. Thus sinus rhythm was restored in 26 of 31 patients. The long-term result is, however, unsatisfactory as II of the 26 patients reverted to arrhythmia in spite of continued use of antiarrhythmics.

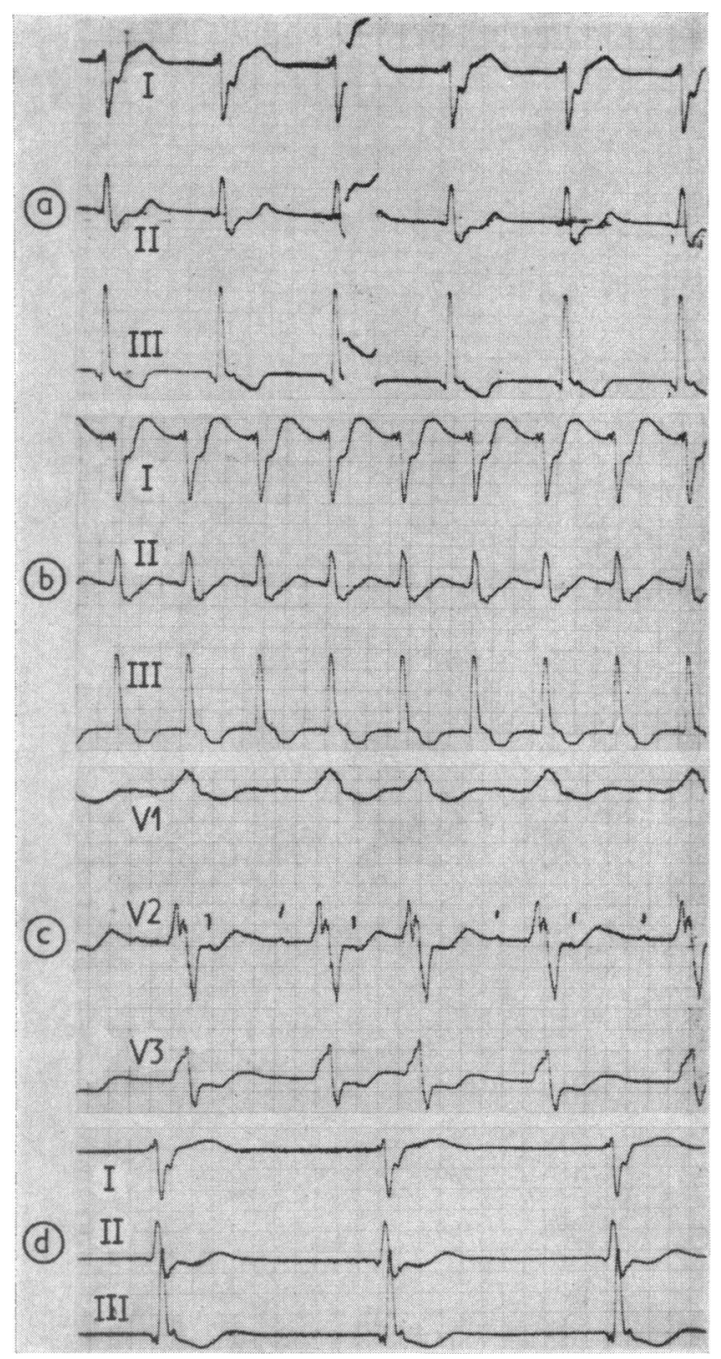

FIG. a) Electrocardiogram I October 1972, showing junctional tachycardia with a ventricular rate of 1 Io. Digitoxin concentration was $40 \mathrm{ng} / \mathrm{ml} ; b) 28$ October 1972, showing supraventricular tachycardia at a rate of $175 ;$ c) 29 October 1972 , showing atrial tachycardia with varying $A V$ block. Digitoxin concentration was $5 \mathrm{ng} / \mathrm{ml}$; d) I February 1973, showing idioventricular rhythm with a rate of 55 . 
The prognosis in our patients was considerably better than in previous reports. Only 2 patients died, one after mitral commissurotomy, and one suddenly one month after leaving hospital.

\section{Discussion}

The following arguments indicate strongly that digitalis intoxication was not an important aetiological factor in these patients (Lown et al., 1960).

I) Atrial tachycardia with block appeared in none of the patients during initial treatment with digitalis or an increase in the maintenance dose.

2) Other subjective and objective stigmata of digitalis intoxication were absent in the majority of patients.

3) Atrial tachycardia with block was not associated with potassium depletion and did not respond to potassium supplements.

4) The serum digitoxin concentration in the group was not found to be higher than in our previously reported material of non-intoxicated patients (Table 3).

The last argument by itself should not be given too much weight. It is well known that there is no sharp distinction between toxic and non-toxic levels of serum digitalis concentration (Beller et al., 1971). Digitalis may cause toxic arrhythmias, either by means of an abnormally high serum concentration of digitalis or by means of an increased myocardial sensitivity to digitalis. Only in the first of these situations can measurement of serum levels identify the cause. However, none of the known factors which may cause hypersensitivity to digitalis (electrolyte disturbances, ischaemia, etc.) was particularly prevalent in the material. Thus, when the serum levels are considered together with the clinical evidence we conclude that digitalis was not a prominent cause of atrial tachycardia with block in our group of patients.

This conclusion is at variance with most of the above-mentioned reports in which the diagnosis of digitalis intoxication had been made from clinical criteria only. It is also in disagreement with the report of Smith and Haber (1970) who found a mean serum digoxin level of $4.1 \pm 1 \cdot 9 \mathrm{ng} / \mathrm{ml}$ (range $2 \cdot 0-8 \cdot 7)$ in 18 patients with supraventricular tachycardia with block compared with the mean level in non-intoxicated patients of $1 \cdot 4 \pm 0.7 \mathrm{ng} / \mathrm{ml}$. In fact, the patients with this arrhythmia had the highest serum levels of any of the subgroups with intoxication.

These discrepancies may be explained to some extent by three factors. First, and most important is patient selection. The patients described by Smith and Haber (1970) were selected on the basis that the arrhythmia reverted when digoxin was discontinued: these authors did not state how many had atrial tachycardia with block in their nonintoxicated group. None of our patients would have fulfilled the criteria of digitalis intoxication applied by Smith and Haber. Our findings may also be related to the type of patients studied. Our hospital is a reference hospital for patients in whom cardiac surgery is considered, and most of them had valvular or congenital heart disease. The type of patient may also have a bearing on the prognosis which, in our study, was better than in most previous reports on atrial tachycardia with block.

Secondly, day-to-day digitalis dosage influences the incidence of digitalis-induced atrial tachycardia with block. In our country, comparatively low doses are used routinely, and therefore the proportion of episodes caused by digitalis will tend to be less.

A third factor may be that the published clinical studies may tend to overrate the importance of digitalis. It may be difficult to establish whether digitalis was 'the cause' or not in individual episodes of atrial tachycardia with block. In most cases it is reasonable to consider not one but several causes, of which digitalis may be more or less prominent. Workers who previously found that digitalis was an important aetiological factor for atrial tachycardia with block may have a greater tendency to report their results than those who did not.

Regarding the treatment of atrial tachycardia with block, we recommend that potassium and

TABLE 3 Summary of digitoxin dosage and serum concentrations in patients with atrial tachycardia with block compared with corresponding data from definitely non-intoxicated patients

\begin{tabular}{|c|c|c|c|c|c|c|c|}
\hline \multirow[t]{2}{*}{ Dose (mg/day) } & \multicolumn{3}{|c|}{ Atrial tachycardia with block } & \multicolumn{3}{|c|}{ Non-intoxicated (Rasmussen et al., I97I) } & \multirow[t]{2}{*}{$P$} \\
\hline & No. & Mean & $S E M$ & No. & Mean & $S E M$ & \\
\hline 0.05 & 4 & 19.4 & $2 \cdot 0$ & 17 & $12 \cdot 0$ & $\mathbf{I} \cdot 3$ & $<0.05$ \\
\hline 0.07 & 15 & $21 \cdot 3$ & $\mathbf{2 \cdot 2}$ & 17 & $16 \cdot 7$ & $1 \cdot 8$ & NS \\
\hline 0.085 & 4 & 16.0 & - & & & & \\
\hline 0.10 & 6 & $24 \cdot I$ & $3 \cdot 3$ & 32 & $18 \cdot 2$ & $\mathbf{I} \cdot \mathbf{I}$ & $=0.05$ \\
\hline
\end{tabular}


digitalis determinations should be carried out immediately. Digitalis should be omitted until the concentration is known, and potassium supplements should be added. The most effective treatment is electroconversion. Atrial tachycardia with block usually responds easily to low energy levels. Various antiarrhythmic drugs may also be tried but there is none that emerges as the drug of choice. Because of the limited number of patients we have inadequate experience in the prophylactic use of long-term antiarrhythmic drugs. Our experience in the last two patients indicates that verapamil is a promising drug in this respect.

\section{References}

Agarwal, B. L., and Agrawal, B. V. (1972). Digitalis induced paroxysmal atrial tachycardia with AV block. British Heart fournal, 34, 330.

Beller, G. A., Smith, T. W., Abelmann, W. H., Haber E., and Hood, W. B., Jr. (1971). Digitalis intoxication. New England fournal of Medicine, 284, 989.

Burton, C. R. (1962). Paroxysmal atrial tachycardia with - atrioventricular block. Canadian Medical Association fournal, 87, 114 .

Freiermuth, L. J., and Jick, S. (1958). Paroxysmal atrial tachycardia with atrioventricular block. American fournal of Cardiology, 1, 584

Gjerdrum, K. (1970). Determination of digitalis in blood. Acta Medica Scandinavica, 187, 37 I.
Goldberg, L. M., Bristow, J. D., Parker, B. M., and Ritzmann, L. W. (I960). Paroxysmal atrial tachycardia with atrioventricular block. Circulation, 21, 499.

Harris, E. A., Julian, D. G., and Oliver, M. F. (1960). Atrial tachycardia with atrioventricular block due to digitalis poisoning. British Medical fournal, 2, 1409.

Hejtmancik, M. R., Herrmann, G. R., and Wright, J. C. (1958). Paroxysmal supraventricular tachycardias complicating organic heart disease. American Heart fournal, 56, 671.

Hillestad, L. (1969). Atrial tachycardia with block. Acta Medica Scandinavica, 186, 439.

Lewis, T. (1909). Paroxysmal tachycardia. Heart, I, 43.

Lowenstein, J. M., and Corrill, E. M. (1966). An improved method for measuring plasma and tissue concentrations of digitalis glycosides. Fournal of Laboratory and Clinical Medicine, 67, 1048.

Lown, B., Wyatt, N. F., and Levine, H. D. (1960). Paroxysmal atrial tachycardia with block. Circulation, 21, 129.

Mackenzie, J. (I9I I). Digitalis. Heart, 2, 273.

Morgan, W. L., and Breneman, G. M. (I962). Atrial tachycardia with block treated with digitalis. Circulation, $25,787$.

Oram, S., Resnekov, L., and Davies, P. (1960). Digitalis as a cause of paroxysmal atrial tachycardia with atrioventricular block. British Medical fournal, 2, 1402.

Rasmussen, K., Jervell, J., and Storstein, O. (I97I). Clinical use of a bio-assay of serum digitoxin activity. European fournal of Clinical Pharmacology, 3, 236.

Smith, T. W., and Haber, E. (1970). Digoxin intoxication: the relationship of clinical presentation to serum digoxin concentration. fournal of Clinical Investigation, 49, 2377.

Requests for reprints to Professor Ole Storstein, Rikshospitalet, Pilestredet 32, Oslo, Norway. 